\title{
Creatine, guanidinoacetate and homoarginine in statin-induced myopathy
}

\author{
Axel Neu ${ }^{1}$ Sönke Hornig ${ }^{1} \cdot$ Ali Sasani $^{2}$ - Dirk Isbrandt ${ }^{3,4} \cdot$ Christian Gerloff $^{2}$ - Dimitris Tsikas ${ }^{5}$. \\ Edzard Schwedhelm ${ }^{6,7} \cdot$ Chi-un $\mathrm{Choe}^{2}(\mathbb{D}$
}

Received: 25 March 2020 / Accepted: 20 June 2020 / Published online: 27 June 2020

(c) The Author(s) 2020

\begin{abstract}
Our study evaluated the effect of creatine and homoarginine in AGAT- and GAMT-deficient mice after simvastatin exposure. Balestrino and Adriano suggest that guanidinoacetate might explain the difference between AGAT- and GAMT-deficient mice in simvastatin-induced myopathy. We agree with Balestrino and Adriano that our data shows that (1) creatine possesses a protective potential to ameliorate statin-induced myopathy in humans and mice and (2) homoarginine did not reveal a beneficial effect in statin-induced myopathy. Third, we agree that guanidinoacetate can be phosphorylated and partially compensate for phosphocreatine. In our study, simvastatin-induced damage showed a trend to be less pronounced in GAMT-deficient mice compared with wildtype mice. Therefore, (phospo) guanidinoacetate cannot completely explain the milder phenotype of GAMT-deficient mice, but we agree that it might contribute to ameliorate statin-induced myopathy in GAMT-deficient mice compared with AGAT-deficient mice. Finally, we agree with Balestino and Adriano that AGAT metabolites should further be evaluated as potential treatments in statin-induced myopathy.
\end{abstract}

Dear editor,

We thank Drs. Balestrino and Adriano for their insightful comments on our publication about the effects of AGAT- and

Handlinf editor: E. Closs.

Chi-un Choe

cchoe@uke.de

1 Experimental Neuropediatrics, Department of Pediatrics, University Medical Center Hamburg-Eppendorf, Hamburg, Germany

2 Department of Neurology, University Medical Center Hamburg-Eppendorf, Martinistraße 52, 20246 Hamburg, Germany

3 German Center for Neurodegenerative Diseases (DZNE), Bonn, Germany

4 University of Cologne, Cologne, Germany

5 Core Unit Proteomics, Hannover Medical School, Institute of Toxicology, Hannover, Germany

6 Institute of Clinical Pharmacology and Toxicology, University Medical Center Hamburg-Eppendorf, Hamburg, Germany

7 German Center for Cardiovascular Research (DZHK), Partner Site Hamburg/Kiel/Lübeck, Hamburg, Germany
GAMT-deficiency in simvastatin-induced myopathy (Balestrino and Adriano 2020). Among all our findings, Balestrino and Adriano point out the increased vulnerability of simvastatin induced myopathy in AGAT-deficient (AGAT ${ }^{-1-}$ ) mice compared with wildtype and GAMT-deficient $\left(\mathrm{GAMT}^{-/-}\right.$) mice (Sasani et al. 2020). $\mathrm{AGAT}^{-/-}$mice are devoid of creatine, homoarginine and guanidinoacetate- the only known products of the AGAT and GAMT pathway.

First, we have shown that creatine reduces simvastatininduced muscle damage in creatine-deficient $\mathrm{AGAT}^{-/-}$mice. This finding in mice is in line with their and other previous work in patients (Balestrino and Adriano 2018; Shewmon and Craig 2010). In mice, we have shown that creatine-deficient $\mathrm{AGAT}^{-1-}$ and $\mathrm{GAMT}^{-/-}$mice reveal a severe myopathy and reduced muscle strength (Nabuurs et al. 2013; Schmidt et al. 2004). Therefore, creatine possesses a protective potential to ameliorate statin-induced myopathy in humans and mice.

Second, homoarginine was studied in statin-induced myopathy, given that we were the first to show that AGAT is mandatory for homoarginine synthesis in mice and humans (Choe et al. 2013). However, our current experiments revealed that homoarginine supplementation in homoarginine-deficient $\mathrm{AGAT}^{-/-}$mice did not affect simvastatininduced myopathy, which is in contrast to homoarginine's 
role in cerebrovascular and cardiac function (Choe et al. 2013; Faller et al. 2018). In mouse models of ischemic stroke and heart failure, homoarginine-but not creatinewas able to improve cerebrovascular damage and normalize cardiac dysfunction in AGAT-deficient mice. We agree with Balestrino and Adriano that although we hypothesized a protective effect of homoarginine in statin-induced myopathy, we did not find any.

The third product of AGAT activity is guanidinoacetate. GAMT-deficient mice are devoid of creatine-as AGATdeficient mice, but have increased AGAT expression and, therefore, higher guanidinoacetate levels. Therefore, Balestrino and Adriano hypothesized that the milder phenotype of GAMT- versus AGAT-deficient mice might rather be explained by elevated guanidinoacetate levels and not AGAT expression itself. Early studies with GAMT-deficient mice and patients revealed that guanidinoacetate can also be phosphorylated in the absence of creatine to partially substitute for phosphocreatine (Kan et al. 2004; Schulze et al. 1997). However, enzyme kinetics and recovery rates after depletion of phospho-guanidinoacetate are considerably slower compared to phosphocreatine. Phospho-guanidinoacetate is not able to fully compensate for the lack of phosphocreatine, because GAMT-deficient mice reveal a reduced muscle strength and histological signs of myopathy (Schmidt et al. 2004). Moreover, in addition to AGAT- and GAMT-deficient mice, we also used wild-type controls in our experiments with normal creatine, normal homoarginine and normal guanidinoacetate levels (Sasani et al. 2020). Interestingly, statin-induced muscle damage and dysfunction showed a trend to be less pronounced in GAMT-deficient mice compared with wild-type mice. Although phospho-guanidinoacetate cannot completely explain the milder phenotype of GAMT-deficient mice, (phosho) guanidinoacetate might contribute to ameliorate statin-induced myopathy in GAMTdeficient mice compared with AGAT-deficient mice as suggested by Balestrino and Adriano (Balestrino and Adriano 2020). In addition to their protective roles as energy buffers, (phospho) guanidinoacetate might have similar pleitropic effects as (phospho) creatine (Wallimann et al. 2011), such as being an osmolyte that protects muscle against exerciseinduced hypertonic stress (Alfieri et al. 2006). Finally, we agree with Balestino and Adriano that AGAT metabolites should further be evaluated as potential treatments in statininduced myopathy.

\section{Acknowledgements Open Access funding provided by Projekt DEAL}

Funding This work was supported by the Werner-Otto-Stiftung (5/86, C.U.C.) and an Else Kröner-Exzellenz-Stipendium by the Else KrönerFreseniusstiftung (2018_EKES.04).

\section{Compliance with ethical standards}

Conflict of interest The authors declare that they have no conflict of interest.

Open Access This article is licensed under a Creative Commons Attribution 4.0 International License, which permits use, sharing, adaptation, distribution and reproduction in any medium or format, as long as you give appropriate credit to the original author(s) and the source, provide a link to the Creative Commons licence, and indicate if changes were made. The images or other third party material in this article are included in the article's Creative Commons licence, unless indicated otherwise in a credit line to the material. If material is not included in the article's Creative Commons licence and your intended use is not permitted by statutory regulation or exceeds the permitted use, you will need to obtain permission directly from the copyright holder. To view a copy of this licence, visit http://creativecommons.org/licenses/by/4.0/.

\section{References}

Alfieri RR1, Bonelli MA, Cavazzoni A, Brigotti M, Fumarola C, Sestili P, Mozzoni P, De Palma G, Mutti A, Carnicelli D, Vacondio F, Silva C, Borghetti AF, Wheeler KP, Petronini PG (2006) Creatine as a compatible osmolyte in muscle cells exposed to hypertonic stress. J Physiol 576(Pt 2):391-401. https://doi.org/10.1113/jphys iol.2006.115006

Balestrino M, Adriano E (2018) Statin-induced myopathy prevented by creatine administration. BMJ Case Rep. https://doi.org/10.1136/ bcr-2018-225395

Balestrino M, Adriano E (2020) Presence of guanidinoacetate may compensate creatine absence and account for less statin-induced muscle damage in GAMT-deficient compared to AGAT-deficient mice. Amino Acids. https://doi.org/10.1007/s00726-020-02838-z

Choe CU, Atzler D, Wild PS, Carter AM, Böger RH, Ojeda F, Simova O, Stockebrand M, Lackner K, Nabuurs C, Marescau B, Streichert T, Müller C, Lüneburg N, De Deyn PP, Benndorf RA, Baldus S, Gerloff C, Blankenberg S, Heerschap A, Grant PJ, Magnus T, Zeller T, Isbrandt D, Schwedhelm E (2013) Homoarginine levels are regulated by L-arginine:glycine amidinotransferase and affect stroke outcome: results from human and murine studies. Circulation 128(13):1451-1461. https://doi.org/10.1161/CIRCULATIO NAHA.112.000580

Faller KME, Atzler D, McAndrew DJ, Zervou S, Whittington HJ, Simon JN, Aksentijevic D, Ten Hove M, Choe CU, Isbrandt D, Casadei B, Schneider JE, Neubauer S, Lygate CA (2018) Impaired cardiac contractile function in arginine:glycine amidinotransferase knockout mice devoid of creatine is rescued by homoarginine but not creatine. Cardiovasc Res 114(3):417-430. https://doi.org/10.1093/cvr/cvx242

Kan HE, Renema WK, Isbrandt D, Heerschap A (2004) Phosphorylated guanidinoacetate partly compensates for the lack of phosphocreatine in skeletal muscle of mice lacking guanidinoacetate methyltransferase. J Physiol 560(Pt 1):219-229

Nabuurs CI, Choe CU, Veltien A, Kan HE, van Loon LJ, Rodenburg RJ, Matschke J, Wieringa B, Kemp GJ, Isbrandt D, Heerschap A (2013) Disturbed energy metabolism and muscular dystrophy caused by pure creatine deficiency are reversible by creatine intake. J Physiol 591(2):571-592. https://doi.org/10.1113/jphysiol.2012.241760

Sasani A, Hornig S, Grzybowski R, Cordts K, Hanff E, Tsikas D, Böger R, Gerloff C, Isbrandt D, Neu A, Schwedhelm E, Choe CU (2020) Muscle phenotype of AGAT- and GAMT-deficient mice after simvastatin exposure. Amino Acids 52(1):73-85. https://doi.org/10.1007/ s00726-019-02812-4 
Schmidt A, Marescau B, Boehm EA, Renema WK, Peco R, Das A, Steinfeld R, Chan S, Wallis J, Davidoff M, Ullrich K, Waldschütz R, Heerschap A, De Deyn PP, Neubauer S, Isbrandt D (2004) Severely altered guanidino compound levels, disturbed body weight homeostasis and impaired fertility in a mouse model of guanidinoacetate $N$-methyltransferase (GAMT) deficiency. Hum Mol Genet 13(9):905-921

Schulze A, Hess T, Wevers R, Mayatepek E, Bachert P, Marescau B, Knopp MV, De Deyn PP, Bremer HJ, Rating D (1997) Creatine deficiency syndrome caused by guanidinoacetate methyltransferase deficiency: diagnostic tools for a new inborn error of metabolism. J Pediatr 131(4):626-631
Shewmon DA, Craig JM (2010) Creatine supplementation prevents statininduced muscle toxicity. Ann Intern Med 153(10):690-692. https:// doi.org/10.7326/0003-4819-153-10-201011160-00024

Wallimann T1, Tokarska-Schlattner M, Schlattner U (2011) The creatine kinase system and pleiotropic effects of creatine. Amino Acids 40(5):1271-1296. https://doi.org/10.1007/s00726-011-0877-3

Publisher's Note Springer Nature remains neutral with regard to jurisdictional claims in published maps and institutional affiliations. 